\title{
Can HBsAg Be Used as a Viral Replication Marker in Chronic Hepatitis B Patients?
}

\author{
Kronik Hepatit B Hastalarında HBsAg Viral Replikasyon Göstergesi Olarak Kullanılabilir mi?
}

\author{
Emel UZUNOĞLU1, Ahmet Melih ŞAHIN², Esin AVCl33, Hakan KUTLU2, Gökçe GÜNTEPE1 \\ ${ }^{1}$ Giresun University Faculty of Medicine, Department of Medical Microbiology, Giresun, Turkey \\ ${ }^{2}$ Giresun University, Prof. Dr. Ilhan Özdemir Training and Research Hospital, Clinic of Clinical Microbiology and Infectious Diseases, Giresun, Turkey \\ ${ }^{3}$ Giresun University Faculty of Science and Literature, Department of Statistics, Giresun, Turkey
}

\begin{abstract}
Objective: Monitoring hepatitis B virus (HBV) treatment responses and virus replication is performed with molecular tests. However, these tests are either expensive or invasive. A new and more practical marker is needed. We aimed to evaluate the correlation between serum hepatitis B surface antigen (HBsAg) and alanine aminotransferase (ALT) levels and HBV DNA level in hepatitis B e antigen $(\mathrm{HBeAg})+/$ - patients and detect whether $\mathrm{HBsAg}$ can be used as a surrogate replication marker instead of HBV DNA.

Material and Methods: A retrospective study was conducted in 59 chronic hepatitis B patients. Serum ALT, HBsAg and HBeAg levels and HBV DNA levels were recorded. The results were analysed with the Mann-Whitney $U$ test and Spearman correlation coefficient. A $p$ value of $\leq 0.05$ was considered statistically significant. Sequential results were compared using Blant-Alpman plot.

Results: The patients were grouped as HBeAg-positive (37.2\%) and HBeAg-negative (62.8\%). Serum ALT levels were elevated in $82 \%$ of $\mathrm{HBeAg}$-positive and $70.2 \%$ of HBeAg-negative subjects. There was a statistically significant difference in HBsAg levels between the groups $(p<0.05)$. However, there was no statistically significant difference in ALT and HBV DNA levels ( $p>0.05$ ). A statistically significant negative correlation was detected between HBsAg and HBV DNA levels in $\mathrm{HBeAg}$-positive patients. No correlation was found between HBsAg and HBV DNA levels in HBeAg-negative subjects $(p<0.05)$. In both $\mathrm{HBeAg-positive} \mathrm{and} \mathrm{-negative} \mathrm{individuals,} \mathrm{there} \mathrm{was} \mathrm{a} \mathrm{positive}$ correlation between serum ALT and HBV DNA levels $(p<0.05)$. BlantAlpman graph did not show an appropriate profile.

Conclusion: We found a negative correlation between HBsAg and HBV DNA levels in $\mathrm{HBeAg}$-positive patients. However, this correlation is not practical in monitoring treatment response and replication. Keywords: Hepatitis B surface antigen, hepatitis B virus DNA, hepatitis B e antigen
\end{abstract}

\section{$\ddot{0 Z}$}

Amaç: Hepatit B virüsüne (HBV) olan tedavi cevabı ve virüs replikasyonun monitorizasyonu moleküler yöntemlerle yapılmaktadır. Ancak bu yöntemler ya pahalı ya da invazivdir. Bu konu da daha uygulanabilir bir belirtece intiyaç vardır. Bu çalışmada hepatit $B$ e antijen ( $\mathrm{HBeAg})+$--hastalarda hepatit B yüzey antijeni (HBsAg), alanin aminotransferaz (ALT) ve HBV DNA düzeyleri arasındaki korelasyonu ve HBsAg'nin HBV DNA yerini alabilecek bir replikasyon göstergesi olarak kullanıı kullanılamayacağını araştırmayı hedefledik.

Gereç ve Yöntemler: Çalışmamız 59 kronik hepatit B hastası ile retrospektif olarak yürütülmüştür. Hastaların serum ALT, HBsAg, HBeAg ve HBV DNA düzeyleri kayıt edilmiştir. Sonuçlar Mann-Whitney $U$ ve Spearman korelasyon testleri aracilı̆ıyla değerlendirilmiştir. $\mathrm{P} \leq 0,05$ anlamlı kabul edilmiştir. Ardışı sonuçlar Blant-Alpman grafiği ile karşılaştııımıştır.

Bulgular: Hastalar HBeAg pozitif $(\% 37,2)$ and $\mathrm{HBeAg}$ negatif $(\% 62,8)$ olarak gruplandırıldı. Serum ALT düzeyleri HBeAg pozitif hastalarda $\% 82, \mathrm{HBeAg}$ negatif hastalarda \%70,2 oranında yüksekti. Gruplar arasında, HBsAg düzeyleri arasında istatistiksel olarak anlamlı fark varken $(p<0,05)$, ALT ve HBV DNA düzeyleri arasında yoktu $(p>0,05)$. $\mathrm{HBeAg}$ pozitif grupta HBsAg ve HBV DNA düzeyleri arasında, anlamlı negatif korelasyon saptanırken $(p<0,05), H B e A g$ negatif olanlarda, HBsAg ve HBV DNA düzeyleri arasında korelasyon yoktu. Hem $\mathrm{HBeAg}$ pozitif hem de negatif grupta, serum ALT ve HBV DNA düzeyleri arasında pozitif bir korelasyon vardı $(p<0,05)$. Blant-Alpman grafiği anlamlı bir profil göstermedi.

Sonuç: $\mathrm{HBeAg}$ pozitif hastalarda HBsAg ve HBV DNA düzeyleri arasında negatif bir korelasyon saptadık. Ancak bu korelasyon ne tedavinin monitorizasyonunda ne de replikasyonun takibinde kullanıma uygun değildir.

Anahtar Kelimeler: Hepatit B yüzey antijeni, hepatit B virüsü DNA, hepatit B e antijen

Uzunoğlu E, Şahin AM, Avcı E, Kutlu H, Güntepe G. Can HBsAg be used as a Viral Replication Marker in Chronic Hepatitis B Patients? Viral Hepat J. 2017;23:55-59. 


\section{Introduction}

Chronic hepatitis $B(C H B)$ is a global health problem affecting 350 million patients and leading to 1 million deaths each year (1). Virological, serological, biochemical and histhopathological markers are used for monitoring treatment response (2). Quantification of intrahepatic hepatitis B virus (HBV) covalently closed circular DNA (ccc DNA) is recommended in evaluating efficacy of anti HBV therapy, however, it requires liver biopsy. Active virus replication can also be detected by quantifying total HBV DNA, however, these molecular-based assays are expensive and they are not available in many centers, especially in developing countries $(3,4)$. Therefore, a surrogate marker which is cheap and more practical is required.

HBV has partially double-stranded and circular genome which encodes four major proteins, including S, P, C and X. The S [hepatitis B surface antigen ( $\mathrm{HBsAg}$ )] protein that we detect by serologic tests and diagnose hepatitis $B$ infection is the main protein of the viral envelope. Hepadnaviridae family members produce a large amount of viral envelope protein (HBsAg). The S protein is found both in intact viral particles and subviral particles which also contain $M$ and $L$ protein but not HBV DNA (5). These proteins are noninfectious but they are immunogenic (3). Both HBsAg and hepatitis $\mathrm{B}$ e antigen $(\mathrm{HBeAg})$ represent viral replication and activation is suspected when an increase is detected in these markers. Although, there have been several studies declaring that there was a positive correlation between viral load and $\mathrm{HBsAg}, \mathrm{HBeAg}$ and alanine aminotransferase (ALT) levels and these markers could be used in monitoring the treatment; this correlation may break down during HBV infection and antiviral therapy $(6,7,8)$.

This study aimed to evaluate the correlation between serum HBsAg and ALT levels and serum HBV DNA level in HBeAg $+/$ - patients and investigate if $\mathrm{HBs} A g$ can be used as a surrogate replication marker instead of HBV DNA in CHB patients.

\section{Materials and Methods}

A retrospective study was conducted in $59 \mathrm{CHB}$ patients who were followed up in our clinical microbiology and infectious diseases clinic and treated with nucleoside analogs between May 2012 and January 2017. The study was approved by Giresun University Prof. Dr. Ilhan Özdemir Training and Research Hospital, Local Ethics Committee (approval no: 08/6, date: 15.11.2017). The patients had been HBsAg-positive for more than 6 months. Of the patients, 28 (47.5\%) were male and 31 (52.50\%) were female. The mean age was $42 \pm 11$ years.

There was no patient co-infected with hepatitis A, hepatitis $C$, hepatitis $E$ and hepatitis $D$ viruses or human immunodeficiency virus. Patients with immune disorders, metabolic liver disease, hepatocellular carcinoma or end-stage liver disease were excluded.
HBsAg, HBeAg, ALT and HBV DNA levels were recorded. Serum ALT levels were analysed with Cobas c 702 biochemical autoanalyser (Roche Diagnostics, Mannheim, Germany). Serum $\mathrm{HBsAg}$ and $\mathrm{HBeAg}$ were detected by electro-chemiluminescence assay with Cobas e 601 (Roche Diagnostics, Mannheim, Germany) wherein the semi quantitative test results was expressed in s/co (sample/cut off). HBV DNA was analysed by quantitative Montania 483 system (Anatolia Gene, Istanbul, Turkey) with Bosphore HBV Quantification kit. Linear limits were $1 \times 101^{-1} \times 10^{9} \mathrm{IU} / \mathrm{mL}$.

\section{Statistical Analysis}

The patients were divided into two groups as HBeAg-positive and -negative. Mean and standard deviations of HBsAg, ALT and HBV DNA levels were calculated. Statistical difference in HBsAg, ALT and HBV DNA levels between HBeAg-positive and -negative groups were analysed with the Mann-Whitney $U$ test. Spearman correlation coefficient was used to correlate serum levels of HBsAg, ALT and HBV DNA levels. SPSS 16 was used for statistical analysis. A $p$ value of $\leq 0.05$ was considered statistically significant. In order to determine whether HBsAg can be used for monitoring treatment, the sequential results of the patients were compared using Blant-Alpman plot.

\section{Results}

The levels of HBsAg, ALT and HBV DNA in HBeAg-positive and -negative groups are shown in Table 1. Of the patients, 22 (37.2\%) were HBeAg-positive and 37 (62.8\%) were HBeAg-negative. In $\mathrm{HBeAg}$-positive and -negative subjects, serum ALT levels were elevated in 18 (82\%) and 26 (70.2\%) patients, respectively.

Viral load was higher in $\mathrm{HBeAg-positive} \mathrm{patients} \mathrm{than} \mathrm{in} \mathrm{HBeAg-}$ negative individuals. On the other hand, HBsAg was higher in $\mathrm{HBeAg}$-negative patients. The distribution of HBsAg levels are shown in Figure 1. Statistical analysis revealed that there was a statistically significant difference in HBsAg levels $(p=0.011)$ between these two groups. However, the difference in ALT and HBV DNA levels was not statistically significant ( $p>0.05$ ).

There was a statistically significant negative correlation between HBsAg and HBV DNA levels in HBeAg-positive patients. On the other hand, no correlation was found between HBsAg and HBV DNA levels in HBeAg-negative patients. In both HBeAgpositive and -negative patients, there was a statistically significant positive correlation between serum ALT and HBV DNA levels $(p<0.05)$ (Table 2).

Blant-Alpman graph was drawn in order to analyze whether HBsAg can be used instead of HBV DNA for monitoring response to treatment but the data did not constitute an appropriate profile (Data not shown).

\begin{tabular}{l}
$\begin{array}{l}\text { Table 1. Median (maximum-minimum) of hepatitis B surface antigen, alanine aminotransferase and hepatitis B virus DNA levels for both hepatitis B e } \\
\text { antigen positive and negative patients }\end{array}$ \\
\hline
\end{tabular}




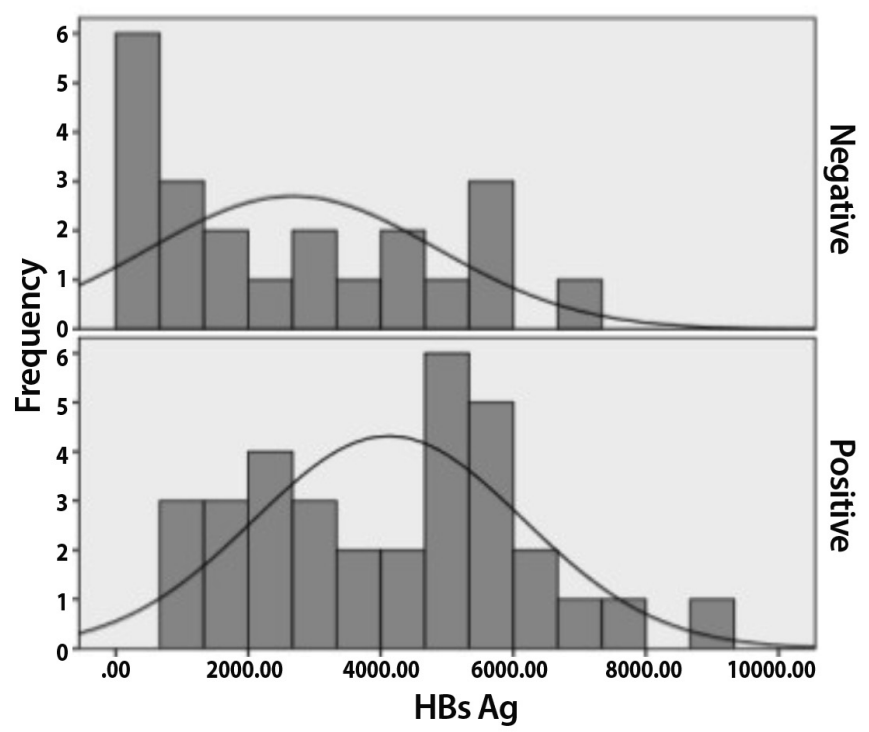

Figure 1. The distribution of serum hepatitis B surface antigen levels in hepatitis $B$ e antigen positive and negative groups HBsAg: Hepatitis B surface antigen

Table 2. Spearman's correlation coefficients showing the correlation between hepatitis $B$ surface antigen, alanine aminotransferase and hepatitis $B$ virus DNA levels in hepatitis $B$ e antigen positive and negative patients

\begin{tabular}{|l|l|l|}
\hline & $\begin{array}{l}\text { HBeAg positive } \\
\text { Spearman RHO }\end{array}$ & $\begin{array}{l}\text { HBeAg negative } \\
\text { Spearman RHO }\end{array}$ \\
\hline HBsAg-HBV DNA & $-0.699^{*}$ & 0.021 \\
\hline ALT-HBV DNA & $0.531^{*}$ & $0.511^{*}$ \\
\hline $\begin{array}{l}\text { *Statistically significance at 5\% level } \\
\text { HBsAg: Hepatitis B surface antigen, HBV: Hepatitis B virüs, HBeAg: Hepatitis Be } \\
\text { antigen, ALT: Alanine aminotransferase, RHO: Speraman's Rank order correlation }\end{array}$ \\
\hline
\end{tabular}

\section{Discussion}

In our study, the difference and correlation between HBsAg and ALT levels and HBV DNA level were investigated in HBeAgpositive and -negative patients. We hypothesized that HBsAg can be used during monitoring response to treatment in $\mathrm{CHB}$ patients. However, in our study, when an increase was detected in HBV DNA levels, a decrease was observed in HBsAg levels or vice versa in $\mathrm{HBeAg}$-positive patients. There was no correlation between HBsAg and HBV DNA levels in HBeAg-negative patients. On the other, hand serum ALT levels were increasing with increasing levels of HBV DNA in both groups.

Several studies investigating the correlation between HBsAg and ALT levels and HBV DNA level in CHB patients have revealed conflicting results $(5,6,7,9,10)$. To our knowledge, researchers detected a correlation between HBsAg and HBV DNA only in HBeAg-positive patients $(3,9,10)$. In a cross-sectional study from Iran, the majority of the cases (87\%) were HBeAg-negative and no correlation was detected between HBsAg and HBV DNA levels (3). Similar results were also demonstrated by Zeng et al. (8) in a Chinese cohort, by Jaroszewicz et al. (11) in a European cohort, by Nguyen et al. (12) in an Asian cohort, and by Ramachandran et al. (13) in an Indian cohort. In our study, $62.8 \%$ of the cases were $\mathrm{HBeAg}$-negative and we also could not find any correlation between HBsAg and HBV DNA in HBeAgnegative patients. Our results revealed that using $\mathrm{HBsAg}$ instead of HBV DNA for monitoring does not seem possible in HBeAgnegative cases.

In HBeAg-positive cases, HBV DNA, which demonstrates viral load, was higher when compared to HBeAg-negative cases but, in contrast, HBsAg was lower. Therefore, there was a negative correlation between $\mathrm{HBs}$ Ag and HBV DNA levels in $\mathrm{HBeAg}$-positive patients. HBsAg and $\mathrm{HBeAg}$ are both accepted as the indicators of viral replication and a positive correlation is expected in fact. In the literature, there are studies that revealed positive correlation as well as many studies demonstrating negative correlation $(5,6,8,14)$. We conclude that a negative correlation was detected in our study due to several different scenarios.

In our laboratory, we use the HBsAg II kit (Roche Diagnostics, Mannheim, Germany) which produces semi-quantitative results wherein the results are expressed in s/co and we do not dilute the samples. However, there is a type of interference which is also called hook effect especially in immunoassays. This effect may cause misdetection of HBsAg due to a very high analyte concentration (15). In order to obtain accurate results, during quantification experiments performed with HBsAg II quantification kits (Roche Diagnostics, Mannheim, Germany), $1 / 400$ times dilution of the samples is suggested by the manufacturer $(16,17)$. On the other hand, Zhang et al. (14) carried out a study with a quantitative kit (Abbott Diagnostics, Germany) and they have diluted the samples to $1: 500$ or 1:1000 if they were greater than $250 \mathrm{lU} / \mathrm{mL}$ according to the manufacturer's instructions. They have subdivided the patients into three groups as immune tolerant (IT), immune clearance (IC) and acute or chronic liver failure (ACLF) considering the phase of the disease. They found a weak correlation between HBsAg and HBV DNA levels in IT and ACLF groups and a modest correlation in IC group. They explained this difference with the degree of immune responses in different stages (14). In a cohort study from China, the researchers also worked with a quantitative kit of Abbott Diagnostics and they found the strongest correlation between $\mathrm{HBsAg}$ and HBV in IC group and the poorest correlation in low replicate and liver cirrhosis groups (8).

HBsAg clearance is a complex phenomenon. In IT phase, the host immune response is not triggered against HBV infected hepatocytes. However, when IC phase begins, depending on the degree of host immune response, the clearance of the virus begins and the level of HBsAg declines. ACLF patients show a dramatic immune response compared with $\mathrm{IC}$ patients and $\mathrm{HBs} A g$ levels are significantly lower in ACLF patients. However, these hepatocytes still synthesize 102-105 HBsAg, which is in number much more than required for formation of complete virus particle and these non infective, filamentous or sphenoid $S$ antigens are detected in the serum. Even novel diagnostic techniques cannot differ the complete virion from these particles and detect total HBsAg levels $(14,8)$. Tuaillon et al. (18) quantified serum HBsAg levels by using four different immunoassay methods and investigated the relationship between HBsAg and HBV DNA levels. They found 
the highest correlation in the early phase of the infection. They declared that in the latest phase of the infection, the correlation between these two parameters was weakest and this was not related with the test used.

Mutation is another important factor that may also affect the efficiency of diagnostic immunoassays and the correlation between the quantitative tests. Mutations in $\mathrm{HBsAg}$ cause false-negative results in diagnostic tests (19). Külah et al. (20) found this mutation rate as $12 \%$ in their study. In addition, $\mathrm{HBeAg}$ production is interrupted secondary to the mutations in pre-core region and it is possible to detect HBV DNA in these cases because of continuing virus replication (21). Therefore, novel diagnostic tools are urgently needed for the antigenicity and immunogenicity analyses of these mutant cases.

ALT levels showed a moderate correlation with HBV DNA results. As the cases were chronic hepatitis patients, this was not a surprising finding. Serial values of the patients were also analysed in order to define whether HBsAg can be used instead of HBV DNA in monitoring the treatment. However, Bland-Alpman plot, which is used to evaluate whether one parameter can be used instead of another, revealed that HBsAg does not seem to be appropriate for being used in monitoring the treatment instead of HBV DNA.

\section{Study Limitations}

There were several limitations of our study. The semiquantitative method we used, the escape HBV mutants that we could not detect, the phase of the disease and/or degree of immune response of the host can be considered as the factors that might affect the serum HBsAg levels.

\section{Conclusion}

In conclusion, serum HBsAg levels were negatively correlated with HBV DNA levels in HBsAg-positive patients, however, this correlation was not strong enough to use HBsAg instead of HBV DNA in monitoring treatment. Another quantification study is planned by our group with quantification kits and patients in different stages of the disease. Furthermore, new test methods which detect both infectious and non infectious virus particles containing $\mathrm{S}$ proteins might be beneficial.

\section{Ethics}

Ethics Committee Approval: The study was approved by Giresun University Prof. Dr. llhan Özdemir Training and Research Hospital, Local Ethics Committee (approval no: 08/6, date: 15.11.2017).

Informed Consent: Retrospective study.

Peer-review: Internally peer-reviewed.

\section{Authorship Contributions}

Surgical and Medical Practices: E.U., A.M.S.., H.K., G.G., Concept: E.U., A.M.S.., H.K., Design E.U., A.M.S., H.K., Data Collection or Processing: E.U., G.G., Analysis or Interpretation: E.U., E.A., G.G., Literature Search: E.U., A.M.Ş., H.K., E.A., G.G., Writing: E.U., A.M.S.., H.K., E.A., G.G.

Conflict of Interest: There is no conflict of interest between the authors.

Financial Disclosure: The authors declared this study received no financial support.

\section{References}

1. Wright TL. Introduction to chronic hepatitis B infection. Am J Gastroenterol. 2006;101(Suppl 1):1-6

2. European Association For The Study Of The Liver. EASL Clinical Practice Guidelines: management of chronic hepatitis B. J Hepatol. 2009;50:227-242

3. Ganji A, Esmaeilzadeh A, Ghafarzadegan K, Helalat H, Rafatpanah $\mathrm{H}$, Mokhtarifar A. Correlation between HBsAg quantitative assay results and HBV DNA levels in chronic HBV. Hepat Mon. 2011;11:342-345

4. Li W, Zhao J, Zou Z, Liu Y, Li B, Sun Y, Li X, Liu S, Cai S, Yao W, Xin $S$, Lu F, Xu D. Analysis of hepatitis B virus intrahepatic covalently closed circular DNA and serum viral markers in treatment-naive patients with acute and chronic HBV infection. PLoS One. 2014:9:e89046.

5. Ozdil B, Cosar AM, Akkiz H, Sandikci MU, Kece C. Negative correlation between viral load and HBsAg levels in chronic HBVinfected patients. Arch Virol. 2009;154:1451-1455.

6. Saglik I, Mutlu D, Ongut G, Guvenc H.I,Akbas H, Ogunc D, Colak D. Comparison of $\mathrm{HBsAg}$ and $\mathrm{HBeAg}$ levels with $\mathrm{HBV}$ DNA and ALT levels in patients with chronic hepatitis B infections. Viral Hepat J. 2013;19;119-122

7. Sener AG, Kirdar S, Serter M, Afsar I, Demir EM, Ceylan C, Aydın $\mathrm{N}$. Investigation of the relationship between serum nitric oxide levels, HBV-DNA and ALT levels in chronic hepatitis B patients. Mikrobiyol Bul. 2009;43:83-89.

8. Zeng LY, Lian JS, Chen JY, Jia HY, Zhang YM, Xiang DR, Yu L, Hu JH, Lu YF, Zheng L, Li LJ, Yang YD. Hepatitis B surface antigen levels during natural history of chronic hepatitis B: a Chinese perspective study. World J Gastroenterol. 2014;20:9178-9184.

9. Martinot-Peignoux $M$, Carvalho-Filho $R$, Lapalus $M$, NettoCardosso AC, Lada $O$, Batrla $R$, Krause $F$, Asselah $T$, Marcellin P. Hepatitis B surface antigen serum level is associated with fibrosis severity in treatment-naive, . e antigen-positive patients. J Hepatol. 2013;58:1089-1095.

10. Seto WK, Wong DK, Fung J, Ip PPC, Yuen JC, Hung IF, La $\mathrm{CH}$, Yuen MF. High hepatitis B surface antigen levels predict insignificant fibrosis in hepatitis B e antigen positive chronic hepatitis B. PLoS One. 2012;7:e43087.

11. Jaroszewicz J, Calle Serrano B, Wursthorn K, Deterding K, Schlue $J$, Raupach R, Flisiak $R$, Bock $C T$, Manns MP, Wedemeyer $H$, Cornberg M. Hepatitis B surface antigen (HBsAg) levels in the natural history of hepatitis B virus(HBV)-infection: a European perspective. J Hepatol. 2010;52:514-522.

12. Nguyen T, Thompson AJ, Bowden $\mathrm{S}$, Croagh $\mathrm{C}$, Bell $\mathrm{S}$, Desmond PV, Levy M, Locarnini SA. Hepatitis B surface antigen levels during the natural history of chronic hepatitis $\mathrm{B}$ : a perspective on Asia. J Hepatol. 2010;52:508-513.

13. Ramachandran J, Ismail AM, Chawla G, Fletcher GJ, Goel A, Eapen CE, Abraham P. Serum HBsAg quantification in treatment-naive Indian patients with chronic hepatitis B. Indian J Gastroenterol. 2014;33:131-135

14. Zhang YM, Yang YD, Jia HY, Zeng LY, Wei Y, Ning Z, Li LJ. HBsAg levels in $\mathrm{HBeAg}$-positive chronic hepatitis $\mathrm{B}$ patients with different immune conditions. World J Gastroenterol. 2014;20:4407-4413.

15. Akhtar K, Sherwani RK, Sofi LA, Sharma A, Singh P. Hook's effect - a rare presentation in HBsAg screening. Indian J Hematol Blood Transfus. 2009;25:27-29.

16. Maylin S, Boyd A, Delaugerre C, Zoulim F, Lavocat F, Simon F, Girard PM, Lacombe K. Comparison between Elecsys HBsAg II and Architect HBsAg OT assays for quantification of Hepatitis B Surface Antigen among Patients Coinfected with HIV and Hepatitis B Virus. Clin Vaccine Immunol. 2012;19:242248. 
17. Gupta E, Pandey P, Kumar A, Sharma MK, Sarin SK. Correlation between two chemiluminescence based assays for quantification of hepatitis B surface antigen in patients with chronic hepatitis B infection. Indian J Med Microbiol. 2015;33:96-100.

18. Tuaillon E, Mondain AM, Nagot N, Ottomani L, Kania D, Nogue E, Rubbo PA, Pageaux GP, Van de Perre P, Ducos J. Comparison of serum HBsAg quantitation by four immunoassays, and relationships of HBsAg level with HBV replication and HBV genotypes. PLoS One. 2012;7:e32143.
19. Hossain MG, Ueda K. Investigation of a Novel Hepatitis B Virus Surface Antigen (HBsAg) Escape Mutant Affecting Immunogenicity. PLoS One. 2017;12:e0167871.

20. Külah C, Cömert F, Özlü N, Eroğlu O, Tekin IÖ. Hepatit B Virus (HBV) Infeksiyonunda Serolojik Belirteçler, Transaminaz Düzeyleri Ve HBV DNA'nın Birlikte Değerlendirilmesi. Viral Hepat J. 2007;12: 111-115.

21. Saab S, Martin P. Tests for acute and chronic viral hepatitis. Finding your way through the alphabet soup of infection and superinfection. Postgrad Med. 2000;107:123-126. 